DOI: $10.31249 / \mathrm{rsm} / 2021.04 .07$

\title{
А.Д. Гронский
}

\section{РЕАКЦИЯ ПАРААМЕНТСКИХ ПАРТИЙ АЕВОГО ТОАКА (СПРАВЕААИВАЯ РОССИЯ И КПРФ) НА БЕАОРУССКИЕ ПОСТВЫБОРНЫЕ ПРОТЕСТЫ В АВГУСТЕ 2020 Г.}

\begin{abstract}
Аннотация. Протесты, которые начались после объявления результатов выборов президента Белоруссии, вызвали интерес в соседних странах. В России многие политические силь высказали свое мнение о ситуации в Белоруссии. Левые партии, имеющие представительство в Государственной думе, также не остались в стороне от общего тренда. Партия «Справедливая Россия» оценила ситуацию достаточно объективно, указав на то, что кризис произошел по вине обеих сторон. Коммунистическая партия Российской Федераџии обвинила в ухудшении ситуачии в Белоруссии белорусскую оппозицию и страны Запада. Российские коммунисты видят ситуацию как противостояние двух систем. Одна система представлена белорусским правящим режсиом. Российские коммунисты оценивают эту систему положительно. Они видят в современной Белоруссии остатки советского наследия, которое сохранил белорусский президент Александр Лукашенко. Вторая система представлена коллективным Западом, который хочет уничтожить завоевания соичиализма. В августе 2020 г. две системы вступили в конфликт на территории Белоруссии. Российские коммунисты оценивают Александра Лукашенко как сторонника «Русского мира», который противостоит западному влиянию. Однако Александр Лукашенко является противником «Русского мира». Об этом белорусский лидер говорил неоднократно. Тем не менее среди российских коммунистов существуют эксперты, которые объективно оценивают ситуацию в Белоруссии, указывая на то, что в современном кризисе виноваты обе стороны.

Текст подготовлен на основе анализа официальных сайтов партии «Справедливая Россия» и Коммунистической партии Российской Федераџии.
\end{abstract}

Ключевые слова: Белоруссия; президентские выборы 2020 г.; массовые протесты; партия «Справедливая Россия»; Коммунистическая партия Российской Федераџии.

Гронский Александр Дмитриевич - кандидат исторических наук, доцент, ведущий научный сотрудник Центра постсоветских исследований, Институт мировой экономики и международных отношений им. Е.М. Примакова РАН (ИМЭМО РАН). Россия, Москва.

E-mail: agronskij@yandex.ru

Web of Science Researcher ID: AAM-2989-2020 
Gronsky A.D. The reaction of the left-wing parliamentary parties (Just Russia and the Communist party) to the Byelorussian post-election protests in august 2020

Abstract. The protests that had begun after announcing the results of the presidential elections in Belarus aroused interest in the neighboring countries. In Russia, many political forces expressed their opinion about the situation in Belarus. The left-wing parties, represented in the State Duma, also did not stay away from the general trend. The «Just Russia» Party assessed the situation fairly objectively, pointing out that both sides of the conflict had caused the crisis. The Communist Party of the Russian Federation blamed the Belarus opposition and Western countries for the deterioration of the situation in Belarus. Russian communists see the situation as a confrontation between two systems. One system is represented by the Belarus ruling regime. Russian communists evaluate this system positively. They see in modern Belarus the remnants of the Soviet heritage, which Belarus President Alexander Lukashenko preserved. The second system is represented by the collective West, which wants to destroy the foundations of socialism. In August 2020, the two systems came into conflict on the Belarus territory. Russian communists rated Alexander Lukashenko as a supporter of the Russian world, which opposed Western influence. However, Alexander Lukashenko is an opponent of the Russian World. The Belarus leader has repeatedly said this. Nevertheless, there are experts among the Russian communists who objectively evaluate the situation in Belarus and point out that both sides are to blame for the current crisis.

The text is based on the analysis of the official websites of the «Just Russia» Party and the Communist Party of the Russian Federation.

Keywords: Byelorussia; 2020 presidential election; mass protests; Just Russia Party; Communist Party of the Russian Federation.

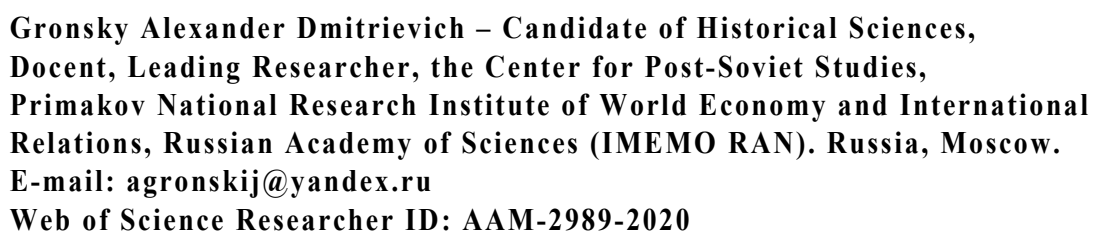

События, начавшиеся после белорусских президентских выборов в Минске и некоторых других городах Белоруссии, вызвали большой резонанс в российских политических кругах. На белорусские протесты отреагировали представители различных политических сил.

Интерес представляет реакция на белорусские события августа 2020 г. российских левых партий, имеющих свое представительство в Государственной думе. Таких партий две - «Справедливая Россия» и Коммунистическая партия Российской Федерации.

Партия «Справедливая Россия» отреагировала на белорусскую ситуацию достаточно поздно. Первые заявления, которые можно найти на партийном 
сайте, датируются 21 августа 2020 г. Их сделали лидер партии Сергей Миронов и заместитель председателя Комитета Госдумы по международным делам, заместитель руководителя фракции «Справедливая Россия» Алексей Чепа.

Миронов, назвав протесты «политическим катаклизмом в братской республике», поддержал высказывание министра иностранных дел РФ Сергея Лаврова по поводу невмешательства в белорусские дела. Миронов заявил, что осуждает «бесчеловечность, жестокость к мирным людям, в какой бы стране они ни жили. Бесчеловечность эта лишь следствием своим имеет жесткие стычки на улицах. В основе ее - неправильное отношение власти к народу, потеря важнейших гуманитарных ориентиров и искажение понятий Свободы и Справедливости». Он попросил российских политиков не называть пятой колонной и «бандеровской сворой» протестующих белорусов, а также жителей Хабаровска, где в то же время проходили протесты в поддержку бывшего губернатора Сергея Фургала. Миронов осознает, что в белорусской ситуации присутствуют интересы Польши, Литвы и Чехии, он говорит об имеющихся в рядах белорусской оппозиции иностранных агентах, но считает, что «никакая зараза не просочится и не рассорит народ с властью, если сама власть не будет пренебрегать своим народом». Роль России в этой ситуации Миронов видит «в гуманитарном содействии для скорейшего установления мира» [Сергей Миронов 2020].

Депутат от «Справедливой России» Чепа оценил протесты как «попытку иностранных государств воспользоваться определенными внутренними проблемами в интересах дестабилизации обстановки внутри страны» и сделал вывод: «Это не что иное, как вмешательство во внутренние дела Беларуси». Чепа указал, что антибелорусские заявления исходят от Литвы, Польши, Украины «и ряда других стран», за которыми стоит более значимая сила, которую депутат не назвал. (Позже директор Службы внешней разведки РФ С.Е. Нарышкин заявил, «что именно США сыграли ключевую роль в подготовке протестов в Белоруссии» [Грибин, Плетнев 2021, с. 11].) Также Чепа предположил, почему малые государства подчиняются этой неназванной силе: «У таких маленьких государств своего ничего нет. Они полностью зависят от определенных мировых структур. Кто этим заправляет и дирижирует нам всем понятно. Поэтому можно предполагать спланированные действия с конкретной стороны» [Алексей Чепа 2020].

27 августа Миронов провел встречу с доцентом МГИМО Кириллом Коктышем, который представил свой взгляд на белорусские события и источники протестов. Миронов в разговоре с Коктышем «выразил надежду, что будет сделано все, чтобы в Белоруссии не повторился украинский сценарий, чтобы обоснованный протест людей не привел к власти националистические и антироссийские силы». Также Миронов выступил за налаживание между властью и протестующими цивилизованного диалога во имя будущего страны [Сергей Миронов провел 2020]. 


\section{РОССИЯ И МИР В ХХІ ВЕКЕ}

28 августа Миронов выступил на телеканале «Россия-24», где снова повторил свое ви́дение ситуации. Он заявил, что, по его мнению, на президентских выборах победил Александр Лукашенко, но с меньшим, чем объявлено, количеством голосов. Говоря о протестующих, Миронов отметил, что их слишком много, чтобы назвать их «пятой колонной» или «оплаченными провокаторами». Миронов выступил за мирное разрешение конфликта, призвал белорусские власти к диалогу с протестующими. В то же время политик отметил, что «раскачать лодку легко, но потом очень сложно восстановить государственность, а судьбы Украины он никому не пожелает». Также Миронов поддержал формирование резерва представителей правоохранительных органов РФ для использования по просьбе белорусских властей, если события примут серьезный оборот, и выразил надежду, что «до его использования дело никогда не дойдет» [Сергей Миронов: хочу 2020].

Куда чаще белорусские события комментировались российскими коммунистами. На сайте КПРФ из 34 новостей за август 2020 г. Лишь четыре не касались белорусской тематики.

Уже вечером 9 августа сайт сообщил о том, что президентские выборы состоялись [В Белоруссии 2020], а в думской фракции КПРФ объявленные результаты выборов были названы ожидаемыми [В Госдуме 2020]. 10 августа лидер партии Геннадий Зюганов заявил, что «нужно поздравить белорусский народ и Лукашенко с прекрасным результатом, а также всех нас, потому что стабильность Белоруссии - это одновременное укрепление стабильности и в РФ». Зюганов высказал свое мнение о белорусских оппозиционерах, назвав их подставными людьми, «которые не хотят добра ни Белоруссии, ни России, а нацелены обслуживать чуждые белорусскому народу интересы», а их деятельность оценил также отрицательно: «... в их выступлениях и программах ничего нет: ни опыта работы, ни уважения к своей истории, ни понимания складывающейся ситуации» [Г.А. Зюганов: Белорусская 2020]. Чуть позже примерно то же самое Зюганов повторил в интервью телеканалу «Красная линия» [Геннадий Зюганов: Белоруссия 2020]. Поздравления Лукашенко были направлены и отдельными членами КПРФ [Н.А. Останина 2020].

10 августа заместитель председателя ЦК КПРФ Дмитрий Новиков заявил, что белорусские выборы «вновь прошли не по лекалам западных модераторов и местных коллаборантов», и обвинил белорусскую оппозицию в реализации американских методичек, подтвердив это обширными цитатами, взятыми из протестных телеграм-каналов. Таким образом, в качестве иллюстрации на сайте КПРФ появились выдержки из методички по расшатыванию белорусского режима телеграм-канала, позже запрещенного белорусскими властями [Дмитрий Новиков 2020]. Также Новиков заявил, что «хотя даже у нас, в России, звучат противоречивые оценки событий, победа Александра Лукашенко - это и наша победа, это победа трудового народа России» [Д.Г. Новиков 2020]. 
12 августа на сайте КПРФ появилось заявление, направленное против белорусских протестов. Ирония заявления, критикующего протестное движение в Белоруссии, в том, что оно было сделано от имени Общероссийского штаба по координации протестного движения, куда входит КПРФ. В заявлении указывалось, что цветные революции стали «испытанным средством мирового капитала по распространению своего влияния», а Общероссийский штаб по координации протестного движения с лукашенковской Белоруссией «объединяет суровая праведная борьба с силами капиталистической экспансии». Также в заявлении транслируется расхожая формула, что «современная Белоруссия это реально работающая альтернатива российской олигархической действительности». Данная формула не учитывает, что белорусская модель на самом деле работает лишь благодаря серьезнейшей экономической и финансовой поддержке Минска «олигархической» Москвой. Вообще, ряд заявлений российских коммунистов базируется на упоминании того, что социально ориентированное белорусское государство, которое выстроил Лукашенко, подверглось угрозе со стороны мирового империализма [Белоруссия 2020]. На сайте КПРФ не обошли вниманием и то, что бело-красно-белая гамма, которая использовалась протестующими в 2020 г., в период Великой Отечественной войны присутствовала на шевронах белорусских коллаборационистов и 30-й добровольческой пехотной дивизии СС (1-й белорусской) [Публицист Александр Трубицын 2020]. Также российские коммунисты поддержали Лукашенко одиночными пикетами возле представительства посольства Белоруссии в Калининграде [Калининградские 2020], критиковали российских деятелей культуры, поддержавших белорусские протесты [Публицист Валентин Симонин 2020], и даже писали стихи [В.И. Кашин 2020]. Коммунисты обратили внимание и на акции в поддержку Лукашенко, прошедшие в августе в Литве, где тоже упоминалось о попытке проведения в Минске цветной революции [Газета «Правда» 2020], и критически отнеслись к попыткам провести в Литве «цепь солидарности» с белорусскими протестующими [Пономарев 2020]. Также коммунисты отрицательно отреагировали на желание канцлера ФРГ Ангелы Меркель задействовать ОБСЕ [В профильном 2020], но призвали провести заседание Парламентского Собрания союза Белоруссии и России [Депутат 2020]. Помимо того, на сайте КПРФ появились статьи члена Компартии Белоруссии Сергея Гришкевича, в которых он описывал свое ви́дение белорусской ситуации [Гришкевич 2020 a; Гришкевич 2020 b].

Очень нелогичное заявление сделал депутат Госдумы от КПРФ Леонид Калашников по поводу 33 «вагнеровцев», которых белорусские власти задержали по подозрению в подготовке массовых беспорядков. Вокруг задержания не только белорусские СМИ, но и белорусская власть «развернули пропагандистский антироссийский ажиотаж. Тон ему задавал сам Лукашенко, публично высказывая претензии в адрес Москвы, вплоть до обвинений в 


\section{РОССИЯ И МИР В ХХІ ВЕКЕ}

заговоре, вместо того чтобы по имеющимся двусторонним каналам межведомственных связей прояснить ситуацию» [Оленченко 2021, с. 58]. Минск не смог доказать свои обвинения и вынужден был отпустить арестованных. Калашников сказал, «что белорусская сторона могла бы наказать задержанных, даже после доказательства того факта, что они были использованы третьими силами», но «это было бы не по-дружески» [В ГД 2020]. Обвинения россиян Минском не подтвердились; почему в таком случае «белорусская сторона могла бы наказать задержанных», коммунисты ответа не дали. Данное задержание - откровенно недружественный шаг Минска в отношении Москвы. Отсутствие со стороны официального Минска извинений за беспочвенные подозрения почему-то не возмутили ни коммунистов, ни остальных политиков. Стоит отметить, что это не первый раз, когда белорусские спецслужбы задерживают россиян или пророссийских публицистов. И Россия лишь изредка проявляла реакцию на эти провокации и никогда не требовала извинений. Необходимо отметить, что накануне выборов белорусские власти открыто заявляли о вмешательстве России, а не Запада в предвыборную ситуацию и подготовку протестов [В белорусском ЦИК 2020; Лукашенко рассказал 2020].

15 августа Геннадий Зюганов призвал к энергичной политической поддержке Белоруссии со стороны России, поскольку, по его мнению, в Белоруссии развивается «оранжевая революция» [Г.А. Зюганов считает 2020]. Достаточно часто коммунисты рассматривают ситуацию в Белоруссии как попытку цветной революции [Геннадий Зюганов: Не отстоим 2020; Не дадим 2020; Станислав Куняев 2020]. При этом полностью игнорируя тот факт, что реализация именно такого «цветного» сценария произошла по вине белорусских властей, сопротивляющихся интеграции и развивающих политику многовекторности. Украинская многовекторность стала одной из причин украинского государственного переворота 2014 г., но белорусские власти это не испугало.

Резкую реакцию коммунистов вызвало интервью депутата Госдумы Константина Затулина, который призвал не признавать состоявшиеся в Белоруссии выборы [Терехов-Круглый 2020]. Первый секретарь Воронежского обкома КПРФ Сергей Рудаков обвинил Затулина в том, что тот поддерживает «двуличие российской элиты, органично слившейся с олигархией», поставил в вину Затулину, что тот не отреагировал на прессинг Павла Грудинина на президентских выборах 2018 г. в России. Интересно, что Рудаков, критикуя ситуацию в России не осознает, что подобная ситуация существует и в Белоруссии. Рудаков пишет: «Затулину же, поборнику демократии, хотим напомнить, как Госдума позорно провела пенсионную реформу, историческое "обнуление”, голосование в три дня. Так что, как говорят в русском народе, “чья бы корова мычала...”” [Рудаков 2020]. Однако Рудаков проигнорировал, что повышение пенсионного возраста в Белоруссии произошло раньше, чем в России, «обнуление» с изменением конституции также произошло раньше, 
чем в России, досрочное голосование не в три дня, а в пять также законодательно действует дольше, чем в России. И все эти явления были претворены в жизнь именно во время правления Лукашенко. При этом Лукашенко критике не подвергается, что ставит под сомнения объективность взгляда на ситуацию.

Представители КПРФ рассматривают Лукашенко как подошедшего «ближе всех из нынешних руководителей стран СНГ к возрождению обновленного Союза как единого государства братских народов, лишенного олигархии и хищной эксплуатации народа» [Рудаков 2020], саму Белоруссию в его правление - как «Брестскую крепость, стоящую на страже славянского единства» [Геннадий Зюганов: Не отстоим 2020], а тех, кому дорог союз Белоруссии и России, призывают не допустить смены власти в последней [Майдану 2020]. При этом коммунисты абсолютно игнорируют то, что именно официальная белорусская власть противится интеграции. Интересен пассаж Зюганова о том, что протесты против Лукашенко можно рассматривать как атаку на «Русский мир» [Геннадий Зюганов: Не отстоим 2020]. Однако изучающие проблему российские исследователи указывают, что «позиция государственной политики "подкармливает" националистические настроения в РБ, направленные на дискредитацию "Русского мира"» [Шалыгина, Кащенко 2020, с. 284], а белорусский лидер «сам поддерживал прозападные организации, которые сейчас выступают против него» [Астахова 2020, с. 16]. Отношение Лукашенко к «Русскому миру» ярко подтверждается его цитатами: «[...] считающие, что белорусская земля - это часть, ну, как они говорят сейчас, "Русского мира" и чуть ли не России, - забудьте» [Лукашенко: Считающие 2015]. «Много в последнее время говорится об идее некоего "Русского мира”. Я так понимаю, это не про нас» [Лукашенко. Обращение 2015]. «Я не понимаю, что такое "Русский мир", вы - тем более, а наш народ вообще не понимает, какой русский мир. ... Не думаю, что он у белорусов нашел какуюто поддержку. А насторожил действительно очень многих» [Стенограмма 2015]. Помимо того, накануне президентских выборов 2020 г. и сразу после них официальная белорусская власть использовала откровенно антироссийскую риторику, обвиняя Россию в подготовке будущих протестов [Еловик 2021, с. 46-49]. А избирательная кампания самого белорусского лидера «практически изначально приобрела антироссийский характер» [Суздальцев 2021, с. 47]. Складывается впечатление, что часть российских коммунистов видит некоего идеального Лукашенко и абсолютно игнорирует его антиинтеграционные выпады и дистанцирование от «Русского мира».

В принципе, риторика КПРФ в отношении белорусских поствыборных событий 2020 г. не слишком разнообразна. Приведенные выше примеры повторяются в большинстве заявлений. Республика - это государство с частично сохранившимся социализмом. Этот тезис не может не вызывать у коммунистов положительных эмоций; Лукашенко - это сильный лидер, сохранивший и при- 


\section{РОССИЯ И МИР В ХХІ ВЕКЕ}

умноживший социалистические достижения, а протестующие однозначно марионетки Запада, оппозиция, стремящаяся разрушить остатки социалистических завоеваний прошлого. Часто белорусские события ассоциируются с Украиной периода рубежа 2013-2014 гг. Россия же рассматривается как следующая жертва Запада, а также как олигархическая страна.

Особняком стоят рассуждения о белорусских событиях августа 2020 г. доктора политических наук, члена Президиума, секретаря ЦК КПРФ Сергея Обухова. Он говорит о проблеме не как политик, склонный мыслить в категориях идеологии, а как ученый. На основе имеющихся данных Обухов пытается понять ситуацию, говорит о проблемах внутри белорусской элиты, указывает, что экстраполяция белорусских событий на Россию - больше пропагандистский подход, чем экспертный анализ и т.д. [Сергей Обухов на НТВ 2020; Сергей Обухов ответил 2020; Сергей Обухов про изменения 2020; Сергей Обухов про очередные 2020; Сергей Обухов про развитие 2020].

Стоит отметить, что представители обеих парламентских партий не реагировали на конкретные факты (например, гибель протестующих, отъезд в Литву экс-кандидата Светланы Тихановской или создание Координационного совета оппозиции и др.), а говорили о протестах в общем. Единственный момент, который отметили обе партии - это обещание Россией вооруженной помощи, если события в Белоруссии примут опасный оборот. Коммунисты отреагировали на заявление Лукашенко 15 августа о готовности Кремля оказать помощь, а справедливороссы - на заявление российского президента 27 августа о формировании резерва правоохранительных органов.

Если сравнивать оценку событий левых парламентских партий и российских либеральных организаций (о взгляде на белорусские протесты российских либералов см.: [Гронский 2020]), то можно заметить, что либералы достаточно слабо представляют, как протекает белорусская поствыборная ситуация и достаточно однозначны в оценках. Левые партии предлагают более разнообразные оценки, указывают на проблемы как внешнего, так и внутреннего происхождения. Справедливороссы видят ошибки с обеих сторон и указывают на вину в доведении ситуации до кризиса не только Запада или белорусской оппозиции, но и власти. Коммунисты менее гибки в оценках, их заявления больше мотивированы партийной идеологией. Тем не менее и среди коммунистов наблюдается попытка говорить именно об анализе ситуации, а не о раздаче идеологических оценок.

\section{Библиография}

Алексей Чепа: Литва и ряд других стран вмешиваются в дела Белоруссии // Справедливая Россия. 2020. 21 авг. URL: https://spravedlivo.ru/10464810 (дата обращения: 18.01.2021).

Астахова С. Белоруссия: политическая ситуация вокруг выборов президента - 2020 // Россия и новые государства Евразии. 2020. № 3. С. 9-24. 
Белоруссия - последний оплот социальных завоеваний! Заявление Московского городского Комитета КПРФ // КПРФ. 2020. 14 авг. URL: https://kprf.ru/party-live/regnews/196494.html (дата обращения: 19.01.2021).

В Белоруссии завершилось голосование на президентских выборах // КПРФ. 2020. 9 авг. URL: https://kprf.ru/international/ussr/196422.html (дата обращения: 19. 01.2021).

В белорусском ЦИК заявили о подготовке в РФ новых групп боевиков // Интерфакс. 2020. 30 июля. URL: https://www.interfax.ru/world/719567 (дата обращения: 20.01.2021).

В ГД уверены, что передача РФ 32 граждан укрепит отношения Москвы и Минска // КПРФ. 2020. 15 авг. URL: https://kprf.ru/dep/gosduma/activities/196504.html (дата обращения: 20.01.2021).

В Госдуме назвали честной победу Лукашенко на выборах // КПРФ. 2020. 11 авг. URL: https://kprf.ru/dep/gosduma/activities/196451.html (дата обращения: 19.01.2021).

В профильном комитете Госдумы не видят оснований подключать ОБСЕ к событиям в Беларуси // КПРФ. 2020. 19 авг. URL: https://kprf.ru/international/ussr/196603.html (дата обращения: 19.01.2021).

В.И. Кашин: Нет белорусскому «майдану»! // КПРФ. 2020. 24 авг. URL: https://kprf.ru/ international/ussr/196675.html (дата обращения: 19.01.2021).

Г.А. Зюганов считает, что меры по поддержке Белоруссии со стороны РФ должны быть более энергичными // КПРФ. 2020. 15 авг. URL: https://kprf.ru/party-live/cknews/196500.html (дата обращения: 20.01.2021).

Г.А. Зюганов: «Белорусская оппозиция защищает чуждые народу интересы» // КПРФ. 2020. 10 авг. URL: https://kprf.ru/party-live/cknews/196426.html (дата обращения: 19.01.2021).

Газета «Правда». В Литве провели акции в поддержку А.Г. Лукашенко // КПРФ. 2020. 25 авг. URL: https://kprf.ru/international/ussr/196691.html (дата обращения: 19.01.2021).

Геннадий Зюганов: «Не отстоим Белоруссию, пожар может вспыхнуть в России» // КПРФ. 2020. 21 авг. URL: https://kprf.ru/party-live/cknews/196625.html (дата обращения: 20.01.2021).

Геннадий Зюганов: Белоруссия показала свою волю // КПРФ. 2020. 10 авг. URL: https:// kprf.ru/party-live/cknews/196428.html (дата обращения: 19.01.2021).

Грибин Н.П., Плетнев В.Я. «Белорусский синдром» в контексте обновленной дорожной карты «цветных революций» // Власть. 2021. № 2. С. 9-21.

Гришкевич С. Газета «Правда» ответила критикам белорусского президента // КПРФ. 2020a. 27 авг. URL: https://kprf.ru/international/ussr/196744.html (дата обращения: 20.01.2021).

Гришкевич С. Газета «Правда». Батьку «на слабо» не возьмешь! // КПРФ. 2020b. 25 авг. URL: https://kprf.ru/international/ussr/196692.html (дата обращения: 20.01.2021).

Гронский А.Д. Отношение российских либеральных партий к протестам в Белоруссии в августе - начале сентября 2020 г. // Общественно-политическая мысль российского либерализма середины XVIII - начала XX в. / Материалы Международной научной конференции. 9-10 октября 2020 г. г. Орёл / Под общ. ред. д-ра ист. наук, проф. Д.В. Аронова. Орел: ОГУ им. И.С. Тургенева, 2020. С. 304-313.

Д.Г. Новиков: Минский майдан не проходит // КПРФ. 2020. 11 авг. URL: https://kprf.ru/ party-live/cknews/196441.html (дата обращения: 19.01.2021).

Депутат Госдумы Владимир Поздняков призывает срочно провести заседание Парламентского Собрания союза Белоруссии и России // КПРФ. 2020. 20 авг. URL: https://kprf.ru/ dep/gosduma/activities/196610.html (дата обращения: 19.01.2021).

Дмитрий Новиков: «Ничто не ново... И у белорусской оппозиции тоже» // КПРФ. 2020. 10 авг. URL: https://kprf.ru/party-live/cknews/196427.html (дата обращения: 19.01.2021).

Еловик А.А. Влияние «российского фактора» на президентские выборы 2020 года в Белоруссии // Свободная мысль. 2021. № 1. С. 43-54. 


\section{РОССИЯ И МИР В ХХІ ВЕКЕ}

Калининградские коммунисты запустили акцию: «Мы за Батьку!» // КПРФ. 2020. 18 авг. URL: https://kprf.ru/party-live/regnews/196584.html (дата обращения: 19.01.2021).

Лукашенко рассказал про «карусели» при сборе подписей и финансирование оппонентов российскими олигархами // NEWS 2 / TUT.BY. 2020. 4 июня. URL: https://news2.ru/story/ 601647/ (дата обращения: 20.01.2021).

Лукашенко А.Г. Обращение с Посланием к белорусскому народу и Национальному собранию // Президент Республики Беларусь. 2015. 29 апр. URL: http://president.gov.by/ru/news ru/view/obraschenie-s-poslaniem-k-belorusskomu-narodu-i-natsionalnomu-sobraniju-11301/ (дата обращения: 20.01.2021).

Лукашенко: «Считающие, что Белоруссия - часть Русского мира, - забудьте» // ИА REGNUM. 2015. 29 янв. URL: https://regnum.ru/news/polit/1889647.html (дата обращения: 20.01.2021).

«Майдану» не бывать в Белоруссии! Заявление Общероссийского штаба по координации протестного движения // КПРФ. 2020. 12 авг. URL: https://kprf.ru/international/ussr/196468.html (дата обращения: 20.01.2021).

Н.А. Останина поздравила А.Г. Лукашенко с избранием на пост Президента Белоруссии // КПРФ. 2020. 10 авг. URL: https://kprf.ru/international/ussr/196431.html (дата обращения: 19.01.2021).

Не дадим из Беларуси сделать вторую Украину! Заявление Московского областного отделения КПРФ // КПРФ. 2020. 17 авг. URL: https://kprf.ru/party-live/regnews/196556.html (дата обращения: 20.01.2021).

Оленченко В. Дестабилизация в Белоруссии: роль стран Балтии // Россия и новые государства Евразии. 2021. № 1. С. 55-71.

Пономарев С. «Оборванная цепь». Почему провалилась акция литовских граждан в «знак солидарности» с протестующими в Минске // КПРФ. 2020. 31 авг. URL: https://kprf.ru/international/ ussr/196801.html (дата обращения: 19.01.2021).

Публицист Александр Трубицын: Партизаны и эсэсовцы // КПРФ. 2020. 17 авг. URL: https://kprf.ru/party-live/opinion/196558.html (дата обращения: 19.01.2021).

Публицист Валентин Симонин: Куда гребете, господа хорошие? // КПРФ. 2020. 23 авг. URL: https://kprf.ru/party-live/opinion/196661.html (дата обращения: 19.01.2021).

Рудаков С.И. «Чья бы корова мычала...» Как депутат Государственной думы пытался позорить президента Белоруссии А.Г. Лукашенко // КПРФ. 2020. 12 авг. URL: https://kprf.ru/partylive/opinion/196469.html (дата обращения: 20.01.2021).

Сергей Миронов провел видеоконференцию с политологом Кириллом Коктышем // Справедливая Россия. 2020. 27 авг. URL: https://spravedlivo.ru/10474410 (дата обращения: 18.01.2021).

Сергей Миронов: Пора прекратить воспринимать любое недовольство граждан как провокацию Запада // Справедливая Россия. 2020. 21 авг. URL: https://spravedlivo.ru/10465810 (дата обращения: 18.01.2021).

Сергей Миронов: Хочу пожелать белорусскому народу мирно решить все проблемы // Справедливая Россия. 2020. 28 авг. URL: https://spravedlivo.ru/10479210 (дата обращения: 18.01.2021).

Сергей Обухов на НТВ: Нам надо спасать Союзное государство России и Белоруссии // КПРФ. 2020. 19 авг. URL: https://kprf.ru/international/ussr/196599.html (дата обращения: 19.01.2021).

Сергей Обухов ответил критикам позиции КПРФ по Белоруссии // КПРФ. 2020. 13 авг. URL: https://kprf.ru/roscrisis/196477.html (дата обращения: 19.01.2021).

Сергей Обухов про изменения ситуации на «белорусском фронте» // КПРФ. 2020. 18 авг. URL: https://kprf.ru/international/ussr/196581.html (дата обращения: 19.01.2021).

Сергей Обухов про очередные сводки с «белорусского фронта» на 14 августа // КПРФ. 2020. 14 авг. URL: https://kprf.ru/international/ussr/196490.html (дата обращения: 19.01.2021). 
Сергей Обухов про развитие событий на «белорусском фронте» // КПРФ. 2020. 12 авг. URL: https://kprf.ru/international/ussr/196470.html (дата обращения: 19.01.2021).

Станислав Куняев: «С кем вы, мастера культуры?» // КПРФ. 2020. 17 авг. URL: https:// kprf.ru/activity/culture/196560.html (дата обращения: 20.01.2021).

Стенограмма встречи Президента Республики Беларусь А.Г. Лукашенко с представителями белорусских и зарубежных средств массовой информации // Президент Республики Беларусь. 2015. 29 янв. URL: http://president.gov.by/ru/news_ru/view/stenogramma-vstrechi-spredstaviteljami-belorusskix-i-zarubezhnyx-smi-10760/ (дата обращения: 20.01.2021).

Суздальцев А.И. Белорусская революция: реакция России // Пути к миру и безопасности. 2021. № 1. С. 44-59.

Терехов-Круглый А. Константин Затулин: Избирательную кампанию Лукашенко можно назвать позорной // Украина.py. 2020. 10 авг. URL: https://ukraina.ru/interview/20200810/ 1028505618.html (дата обращения: 20.01.2021).

Шалыгина Н.В., Кащенко Т.Л. «Праздник непослушания» по-белорусски (о ценностях современной белорусской молодежи) // Власть. 2020. № 6. С. 278-285.

\section{References}

Aleksej Chepa: Litva i ryad drugih stran vmeshivayutsya v dela Belorussii [Alexey Chepa: Lithuania and a some other countries interfere in the affairs of Belarus] // Spravedlivaya Rossiya. 2020. 21 Aug. URL: https://spravedlivo.ru/10464810 (data of access: 18.01.2021). (In Russ.)

Astakhova S. Belorussiya: politicheskaya situaciya vokrug vyborov prezidenta - 2020 [Belarus: Political Situation around the Presidential Election - 2020] // Rossiya i novye gosudarstva Evrazii [Russia and the new States of Eurasia]. 2020. N 3. P. 9-24. (In Russ.)

Belorussiya - poslednij oplot social'nyh zavoevanij! Zayavlenie Moskovskogo gorodskogo Komiteta KPRF [Belarus is the last stronghold of social conquests! Statement of the Moscow City Committee of the Communist Party of the Russian Federation] // KPRF. 2020. 14 Aug. URL: https://kprf.ru/party-live/regnews/196494.html (data of access: 19.01.2021). (In Russ.)

D.G. Novikov: Minskij majdan ne prohodit [D.G. Novikov: The Minsk Maidan does not pass!] // KPRF. 2020. 11 Aug. URL: https://kprf.ru/party-live/cknews/196441.html (data of access: 19.01.2021). (In Russ.)

Deputat Gosdumy Vladimir Pozdnyakov prizyvaet srochno provesti zasedanie Parlamentskogo Sobraniya soyuza Belorussii i Rossii [State Duma Deputy Vladimir Pozdnyakov calls for an urgent meeting of the Parliamentary Assembly of the Union of Belarus and Russia] // KPRF. 2020. 20 Aug. URL: https://kprf.ru/dep/gosduma/activities/196610.html (data of access: 19.01.2021). (In Russ.)

Dmitrij Novikov: «Nichto ne novo... I u belorusskoj oppozicii tozhe» [Dmitry Novikov: «Nothing is new... And the Belarusian opposition, too»] // KPRF. 2020. 10 Aug. URL: https://kprf.ru/partylive/cknews/196427.html (data of access: 19.01.2021). (In Russ.)

Elovik A.A. Vliyanie «rossijskogo faktora» na prezidentskie vybory 2020 goda v Belorussii [Influence of the «Russian factor» on presidential elections of 2020 in Belarus] // Svobodnaya mysl' [Free thought]. 2021. N 1. P. 43-54. (In Russ.)

G.A. Zyuganov schitaet, chto mery po podderzhke Belorussii so storony RF dolzhny byt' bolee energichnymi [G.A. Zyuganov believes that measures to support Belarus from the Russian Federation should be more energetic] // KPRF. 2020. 15 Aug. URL: https://kprf.ru/party-live/cknews/196500. html (data of access: 20.01.2021). (In Russ.)

G.A. Zyuganov: «Belorusskaya oppoziciya zashchishchaet chuzhdye narodu interesy» [G.A. Zyuganov: «The Belarusian opposition defends interests alien to the people»] // KPRF. 2020. 10 Aug. URL: https://kprf.ru/party-live/cknews/196426.html (data of access: 19.01.2021). (In Russ.) 


\section{РОССИЯ И МИР В ХХІ ВЕКЕ}

Gazeta «Pravda». V Litve proveli akcii v podderzhku A.G. Lukashenko [Pravda newspaper. Actions in support of A.G. Lukashenko held in Lithuania] // KPRF. 2020. 25 Aug. URL: https://kprf.ru/ international/ussr/196691.html (data of access: 19.01.2021). (In Russ.)

Gennadij Zyuganov: «Ne otstoim Belorussiyu, pozhar mozhet vspyhnut' v Rossii» [Gennady Zyuganov: «If we do not defend Belarus, a fire may break out in Russia»] // KPRF. 2020. 21 Aug. URL: https://kprf.ru/party-live/cknews/196625.html (data of access: 20.01.2021). (In Russ.)

Gennadij Zyuganov: Belorussiya pokazala svoyu volyu [Gennady Zyuganov: Belarus has shown its will] // KPRF. 2020. 10 Aug. URL: https://kprf.ru/party-live/cknews/196428.html (data of access: 19.01.2021). (In Russ.)

Gribin N.P., Pletnyov V.Y. «Belorusskij sindrom» v kontekste obnovlennoj dorozhnoj karty «cvetnyh revolyucij» [The «Belarusian syndrome» in the context of the updated roadmap of color revolutions] // Vlast' [Power]. 2021. N 2. P. 9-21. (In Russ.)

Grishkevich S. Gazeta «Pravda» otvetila kritikam belorusskogo prezidenta [Grishkevich S. Pravda newspaper responds to critics of the Belarusian president] // KPRF. 2020. 27 Aug. URL: https://kprf.ru/international/ussr/196744.html (data of access: 20.01.2021). (In Russ.)

Grishkevich S. Gazeta «Pravda». Bat'ku «na slabo» ne voz'myosh'! [Grishkevich S. Newspaper «Pravda». You can't take the Father «on weak»!] // KPRF. 2020. 25 Aug. URL: https://kprf.ru/ international/ussr/196692.html (data of access: 20.01.2021). (In Russ.)

Gronskij A.D. Otnoshenie rossijskih liberal'nyh partij k protestam v Belorussii v avguste nachale sentyabrya $2020 \mathrm{~g}$. [The attitude of Russian liberal parties to the protests in Byelorussia in August-early September 2020] // Obshchestvenno-politicheskaya mysl' rossijskogo liberalizma serediny XVIII - nachala XX v. [Socio-political thought of Russian liberalism in the mid-XVIII early XX centuries] / Vaterialy Mezhdunarodnoj nauchnoj konferencii. 9-10 Okt. 2020 g. g. Oryol / Pod obshchej redakciej doktora istoricheskih nauk, professora D.V. Aronova. Oryol: OGU im I.S. Turgeneva, 2020. S. 304-313.

Kaliningradskie kommunisty zapustili akciyu: «My za Bat'ku!» [Kaliningrad communists launched a campaign: «We are for the Father! »] // KPRF. 2020. 18 Aug. URL: https://kprf.ru/partylive/regnews/196584.html (data of access: 19.01.2021). (In Russ.)

Lukashenko A.G. Obrashchenie s Poslaniem k belorusskomu narodu i Nacional'nomu sobraniyu [Lukashenko A.G. Address to the Belarusian people and the National Assembly] // Prezident Respubliki Belarus'. 2015. 29 Apr. URL: http://president.gov.by/ru/news_ru/view/obraschenie-s-poslaniemk-belorusskomu-narodu-i-natsionalnomu-sobraniju-11301/ (data of access: 20.01.2021). (In Russ.)

Lukashenko rasskazal pro «karuseli» pri sbore podpisej i finansirovanie opponentov rossijskimi oligarhami [Lukashenko spoke about «carousels» when collecting signatures and financing opponents by Russian oligarchs] // NEWS2. TUT.BY. 2020. 4 Jun. URL: https://news2.ru/story/601647/ (data of access: 20.01.2021). (In Russ.)

Lukashenko: «Schitayushchie, chto Belorussiya - chast' Russkogo mira, - zabud'te» [Lukashenko: «Those who believe that Belarus is part of the Russian world, forget it»] // IA REGNUM. 2015. 29 Jan. URL: https://regnum.ru/news/polit/1889647.html (data of access: 20.01.2021). (In Russ.)

«Majdanu» ne byvat' v Belorussii! Zayavlenie Obshcherossijskogo shtaba po koordinacii protestnogo dvizheniya [«Maidan» will not be in Belarus! Statement of the All-Russian Headquarters for the Coordination of the Protest Movement] // KPRF. 2020. 12 Aug. URL: https://kprf.ru/international/ ussr/196468.html (data of access: 20.01.2021). (In Russ.)

N.A. Ostanina pozdravila A.G. Lukashenko $s$ izbraniem na post Prezidenta Belorussii [N.A. Ostanina congratulated A.G. Lukashenko on his election as President of Belarus] // KPRF. 2020. 10 Aug. URL: https://kprf.ru/international/ussr/196431.html (data of access: 19.01.2021). (In Russ.)

Ne dadim iz Belarusi sdelat' vtoruyu Ukrainu! Zayavlenie Moskovskogo oblastnogo otdeleniya KPRF [We will not allow Belarus to make a second Ukraine! Statement of the Moscow regional 
branch of the Communist Party] // KPRF. 2020. 17 Aug. URL: https://kprf.ru/party-live/regnews/ 196556.html (data of access: 20.01.2021). (In Russ.)

Olenchenko V. Destabilizaciya v Belorussii: rol' stran Baltii [Destabilization in Belarus: Role of the Baltic States] // Rossiya i novye gosudarstva Evrazii [Russia and the new States of Eurasia]. 2021. N 1. P. 55-71. (In Russ.)

Ponomarev S. «Oborvannaya cep'». Pochemu provalilas' akciya litovskih grazhdan v «znak solidarnosti» S protestuyushchimi v Minske [Ponomarev S. «The broken chain». Why the action of Lithuanian citizens in "solidarity» with the protesters in Minsk failed] // KPRF. 2020. 31 Aug. URL: https://kprf.ru/international/ussr/196801.html (data of access: 19.01.2021). (In Russ.)

Publicist Aleksandr Trubicyn: Partizany i esesovcy [Publicist Alexander Trubitsyn: Partisans and SS men] // KPRF. 2020. 17 Aug. URL: https://kprf.ru/party-live/opinion/196558.html (data of access: 19.01.2021). (In Russ.)

Publicist Valentin Simonin: Kuda grebyote, gospoda horoshie? [Publicist Valentin Simonin: Where are you rowing, good gentlemen?] // KPRF. 2020. 23 Aug. URL: https://kprf.ru/party-live/ opinion/196661.html (data of access: 19.01.2021). (In Russ.)

Rudakov S.I. «Ch'ya by korova mychala...» Kak deputat Gosudarstvennoj Dumy pytalsya pozorit' prezidenta Belorussii A.G. Lukashenko [Rudakov S.I. «Look who's talking...» As a deputy of the State Duma tried to shame the President of Belarus A.G. Lukashenko] // KPRF. 2020. 12 Aug. URL: https://kprf.ru/party-live/opinion/196469.html (data of access: 20.01.2021). (In Russ.)

Sergej Mironov provel videokonferenciyu s politologom Kirillom Koktyshem. [Sergey Mironov held a video conference with political scientist Kirill Koktysh] // Spravedlivaya Rossiya. 2020. 27 Aug. URL: https://spravedlivo.ru/10474410 (data of access: 18.01.2021). (In Russ.)

Sergej Mironov: hochu pozhelat' belorusskomu narodu mirno reshit' vse problemy. [Sergey Mironov: I would like to wish the Belarusian people to solve all their problems peacefully] // Spravedlivaya Rossiya. 2020. 28 Aug. URL: https://spravedlivo.ru/10479210 (data of access: 18.01.2021). (In Russ.)

Sergej Mironov: pora prekratit' vosprinimat' lyuboe nedovol'stvo grazhdan kak provokaciyu Zapada [Sergey Mironov: it's time to stop perceiving any discontent of citizens as a provocation of the West] // Spravedlivaya Rossiya. 2020. 21 Aug. URL: https://spravedlivo.ru/10465810 (data of access: 18.01.2021). (In Russ.)

Sergej Obuhov na NTV: Nam nado spasat' Soyuznoe gosudarstvo Rossii i Belorussii [Sergey Obukhov on NTV: We need to save the Union State of Russia and Belarus] // KPRF. 2020. 19 Aug. URL: https://kprf.ru/international/ussr/196599.html (data of access: 19.01.2021). (In Russ.)

Sergej Obuhov otvetil kritikam pozicii KPRF po Belorussii [Sergei Obukhov responded to critics of the Communist Party's position on Belarus] // KPRF. 2020. 13 Aug. URL: https://kprf.ru/ roscrisis/196477.html (data of access: 19.01.2021). (In Russ.)

Sergej Obuhov pro izmeneniya situacii na «belorusskom fronte» [Sergey Obukhov about changes in the situation on the «Belarusian front»] // KPRF. 2020. 18 Aug. URL: https://kprf.ru/ international/ussr/196581.html (data of access: 19.01.2021). (In Russ.)

Sergej Obuhov pro ocherednye svodki s belorusskogo fronta na 14 avgusta [Sergey Obukhov about the next reports from the Belarusian front on August 14] // KPRF. 2020. 14 Aug. URL: https://kprf.ru/international/ussr/196490.html (data of access: 19.01.2021). (In Russ.)

Sergej Obuhov pro razvitie sobytij na «belorusskom fronte» [Sergey Obukhov about the development of events on the «Belarusian front»] // KPRF. 2020. 12 Aug. URL: https://kprf.ru/ international/ussr/196470.html (data of access: 19.01.2021). (In Russ.)

Shalygina N.V., Kashchenko T.L. «Prazdnik neposlushaniya» po-belorusski (o cennostyah sovremennoj belorusskoj molodezhi) [The Belarus' «holiday of disobedience» (the main values and meanings of modern Belarusian youth)] // Vlast' [Power]. 2020. N 6. P. 278-285. (In Russ.) 


\section{РОССИЯ И МИР В ХХІ ВЕКЕ}

Stanislav Kunyaev: «S kem vy, mastera kul'tury?» [Stanislav Kunyaev: «Who are you with, masters of culture? »] // KPRF. 2020. 17 Aug. URL: https://kprf.ru/activity/culture/196560.html (data of access: 20.01.2021). (In Russ.)

Stenogramma vstrechi Prezidenta Respubliki Belarus' A.G. Lukashenko s predstavitelyami belorusskih i zarubezhnyh sredstv massovoj informacii [Transcript of the meeting of the President of the Republic of Belarus Alexander Lukashenko with representatives of the Belarusian and foreign mass media] // Prezident Respubliki Belarus'. 2015. 29 Jan. URL: http://president.gov.by/ru/news_ru/ view/stenogramma-vstrechi-s-predstaviteljami-belorusskix-i-zarubezhnyx-smi-10760/ (data of access: 20.01.2021). (In Russ.)

Suzdaltsev A.I. Belorusskaya revolyuciya: reakciya Rossii [Russia's reaction to the revolution in Belarus] // Puti k miru i bezopasnosti [Ways to peace and security]. 2021. N 1. P. 44-59. (In Russ.)

Terekhov-Kruglyj A. Konstantin Zatulin: Izbiratel'nuyu kampaniyu Lukashenko mozhno nazvat' pozornoj [Konstantin Zatulin: Lukashenko's election campaign can be called shameful] // Ukraina.ru. 2020. 10 Aug. URL: https://ukraina.ru/interview/20200810/1028505618.html (data of access: 20.01.2021). (In Russ.)

V Belorussii zavershilos' golosovanie na prezidentskih vyborah [In Belarus, the voting in the presidential elections has ended] // KPRF. 2020. 9 Aug. URL: https://kprf.ru/international/ussr/ 196422.html (data of access: 19.01.2021). (In Russ.)

V belorusskom CIK zayavili o podgotovke v RF novyh grupp boevikov [The Belarusian CEC announced the preparation of new militant groups in the Russian Federation] // Interfaks. 2020. 30 July. URL: https://www.interfax.ru/world/719567 (data of access: 20.01.2021). (In Russ.)

V GD uvereny, chto peredacha RF 32 grazhdan ukrepit otnosheniya Moskvy i Minska [The State Duma is confident that the transfer of 32 citizens to the Russian Federation will strengthen relations between Moscow and Minsk] // KPRF. 2020. 15 Aug. URL: https://kprf.ru/dep/gosduma/ activities/196504.html (data of access: 20.01.2021). (In Russ.)

V Gosdume nazvali chestnoj pobedu Lukashenko na vyborah [In the State Duma, Lukashenko's victory in the elections was called fair] // KPRF. 2020. 11 Aug. URL: https://kprf.ru/dep/gosduma/ activities/196451.html (data of access: 19.01.2021). (In Russ.)

V profil'nom komitete Gosdumy ne vidyat osnovanij podklyuchat' OBSE k sobytiyam v Belarusi [The profile Committee of the State Duma sees no reason to involve the OSCE in the events in Belarus] // KPRF. 2020. 19 Aug. URL: https://kprf.ru/international/ussr/196603.html (data of access: 19.01.2021). (In Russ.)

V.I. Kashin: Net belorusskomu «majdanu»! [V.I. Kashin: No to the Belarusian «Maidan»!] // KPRF. 2020. 24 Aug. URL: https://kprf.ru/international/ussr/196675.html (data of access: 19.01.2021). (In Russ.) 